удк 334,722

\title{
Оксана ПУКАЛО
}

\section{ТЕОРЕТИЧНІ ПРОБЛЕМИ ТА ПЕРСПЕКТИВИ РОЗВИТКУ МАЛОГО БІЗНЕСУ В УКРАЇНI}

Проаналізовано стан малого бізнесу в Україні, визначено фрактори, які негативно впливають на його розвиток, запропоновано шляхи їх подолання у сучасних умовах господарювання. Охарактеризовано основні фунниіїдрібного бізнесу, висунуто пропозиції щодо його включення у реалізацію загальної стратегії економічного зростання в Україні. Малий бізнес - найдинамічніший елемент структури національної економіки та вагома складова ї системи економічних відносин. Він сприяє встановленню конкурентних засад, оскільки є антимонопольним за своєю економічною суттю. Мале підприємництво як провідний сектор ринкової економіки, забезпечуючи ринок товарами та послугами, $\epsilon$ автономним у здійсненні своєї господарської діяльності, розпоряджається готовою продукцією та прибутком, який залишається після сплати податків та інших зобов'язань. Зроблено висновок, що з метою кращого фрункціонування малого підприємниитва необхідно удосконалити структуру наукових програм з питань підприємницької діяльності. Важливим аспектом ведення малого бізнесу є поширення досвіду його фрункціонування через практику проведення конференцій, семінарів, засідань круглих столів, фрорумів, міжнародних зустрічей. З огляду на процеси децентралізації, нагальнимє створення та ефрективне використання мережі регіональних і цільових фрондів з підтримки підприємниитва у місцевих територіальних громадах, запровадження прогресивного механізму кредитно-гарантійноїта фрінансовоїдопомоги. Головною проблемою розвитку малого бізнесує недостатня ресурсна база:як матеріально-технічна, так і фінансова.

Зазначено, що упродовж тривалого періоду розвиток малого підприємництва уповільнюється негативно діючими чинниками: кризовим станом вітчизняного товарного виробництва, зростанням цін, інфляцією, низьким рівнем платоспроможності населення, корупцією тощо. Зокрема громіздка система бухгалтерського обліку, фрінансова та податкова звітності спричиняють додаткові витрати для підприємств. Гальмівними чинниками щодо розвитку малого бізнесу в Україні $\epsilon$ недосконала чинна нормативно-правова база, а також трудомісткий процес реєстрації нових малих підприємств, що потребує значних фрінансових ресурсів. Закцентовано увагу на тому, що максимальне спрощення регулятивних актів у сфері малого бізнесу уможливило б зниження рівня існуючої корупиї̈, покращило б існуючий там інвестиційний клімат і створило б перспективу економічного зростання.

Ключові слова: мале підприємництво, підприємницька діяльність, обсяг основного капіталу, причини та проблеми розвитку, регіональний рівень, ефективність розвитку, валовий внутрішній продукт.

JEL: B 10

(с) Оксана Пукало, 2017. 
О. Пукало

Теоретичні проблеми та перспективи ...

Постановка проблеми. Сучасна вітчизняна практика господарювання і світовий досвід свідчать, що найважливішою ознакою ринкової економіки є існування і взаємодія великих, середніх і малих підприємств. Малий бізнес є найдинамічнішим елементом структури національної економіки, оскільки він оперативно змінюється під дією ринкової кон'юнктури. Позитивні результати розвитку малого і середнього підприємництва в країнах, які пройшли етап реформування економічної системи, зокрема набутий власний досвід, свідчать про те, що мале підприємництво здатне забезпечувати її інноваційну активність і підтримувати конкурентне середовище. Малий бізнес є одним із механізмів усунення диспропорцій на окремих товарних ринках, засобом створення додаткових робочих місць, а відтак і скорочення безробіття.

Важливо зазначити, що малий бізнес сприяє становленню конкурентних відносин, оскільки є антимонопольним за своєю економічною суттю. Спроможність малого бізнесу швидко реагувати на тенденції ринку й розробляти нові товари для задоволення потреб споживачів визнана великими компаніями. Тому процес активізації розвитку малого підприємництва в українській державі $€$ особливо актуальним сьогодні з огляду на використання його як одного із важливих інструментів вирішення назрілих соціальноекономічних завдань.

Аналіз останніх досліджень і публікацій. Актуальні проблеми малого підприємства в Україні аналізувались у працях вітчизняних дослідників: В. Виговської, З. Варналія, А. Мельник, Г. П'ятницької, М. Харченко, Л. Лебедєвої, Ю. Долгорукова та інших. Однак залишаються недостатньо висвітленими та потребують подальшого дослідження питання, пов'язані 3 модифрікацією причин та проблем, які гальмують розвиток малого підприємництва в Україні.

Мета статті полягає у комплексному аналізі стану малого бізнесу в Україні, визначенні чинників, які негативно впливають на його розвиток, пошуку шляхів подолання негативних фракторів розвитку малого бізнесу в сучасних умовах господарювання.

Виклад основного матеріалу дослідження. Дрібне підприємництво - це самостійна діяльність, пов'язана з виробництвом продукції, наданням послуг тощо з метою отримання прибутку, яка здійснюється фрізичними і юридичними особами, що зареєстровані як суб'єкт підприємницької діяльності, передбачені законодавством. Його правове регулювання підприємницької діяльності в Україні забезпечується законами та іншими нормативними актами, серед яких визначальними є Закони України “Про підприємництво” від 7 лютого 1991 р., "Про підприємства в Україні” від 27 березня 1991 р., "Про господарські товариства” від 10 вересня 1991 р. (усі - зі змінами і доповненнями) [1].

Мале підприємництво - це вагомий сектор національної ринкової економіки, який забезпечує ринок товарами та послугами і створює здорову конкуренцію на ринку праці. Тому саме Закон України “Про підприємництво" визначає загальні правові, економічні та соціальні засади підприємницької діяльності (підприємництва) громадян та юридичних осіб на території України, встановлює гарантії свободи підприємництва та його державної підтримки.

Малий бізнес утверджується шляхом створення розгалуженої системи організації таких підприємств. Згідно із Законом України “Про підприємства”, одним з критеріїв віднесення до малого підприємства є кількість зайнятих на ньому працівників, зокрема:

- у промисловості й будівництві - до 200 осіб;

- у науково-дослідному секторі - до 100 осіб; 
-в інших галузях виробничої сфери (крім роздрібної торгівлі) - до 50 осіб;

-у галузях нематеріального виробництва - до 25 осіб;

-у роздрібній торгівлі - до 15 осіб [2].

На наш погляд, зазначений критерій є одним із визначальних, що характеризує мале підприємство. Як відомо, в інших країнах також застосовується цей показник. Наприклад, в Італії малий бізнес охоплює підприємства з чисельністю до 500 працівників. Однакє велика кількість виробництв, де задіяні менше, ніж 20 робітників.

Для виокремлення малих підприємств також використовуються показники кількості зайнятих, обсягу капіталу. В Японії до категорії малих і середніх підприємств у галузях оборонної промисловості, в будівництві, на транспорті, зв'язку, комунальному господарстві належать юридично самостійні компанії з кількістю до 300 осіб, або обсягом основного капіталу до 100 млн. єн, в оптовій торгівлі - до 100 осіб або до 30 млн. єн, в роздрібній торгівлі й сфрері послуг - до 50 працівників або до $10 \mathrm{mлн.} є$ н.

Досвід функціонування малих підприємств засвідчує здійснення ним своєї діяльності у всіх сферах і галузях народного господарства, при цьому виконуючи один або декілька його напрямів $[3,21]$. Малі підприємства є автономними у здійсненні своєї господарської діяльності, розпоряджаються готовою продукцією, прибутком, який залишається після сплати податків та інших зобов'язань. Як економічна категорія мале підприємництво - це особливий підвид підприємництва, що полягає у створенні і практичній реалізації нового економічного процесу, що пов'язаний з підприємницькою діяльністю громадян - фізичних осіб з метою отримання прибутку за умови особистої зацікавленості суб'єкта підприємництва в ній і задоволення при цьому певних потреб суспільства $[4,3]$.

Проведені дослідження дають змогу стверджувати, що малий бізнес в Україні визначається певними рисами, які суттєво відрізняють його від підприємництва більшості зарубіжних країн, зокрема:

- низьким рівнем технічного оснащення при суттєвому інноваційному потенціалі;

- слабким управлінським рівнем, недостатністю знань, досвіду та культури у сфері ринкових відносин;

-відсутністю системи самоорганізації та недостатністю інфрраструктури щодо підтримки малого підприємництва.

Тому сьогодні мале підприємництво у нашій країні перебуває у кризовому стані в усіх сферах національної економіки: промисловості, сільському господарстві, сфері послуг. Як стверджують українські вчені, його розвиток наштовхується на значні перешкоди [5, 22]. Сьогодні головна проблема малого та середнього бізнесу - недостатня як матеріальнотехнічна, так і фінансова ресурсна база. Практично мова йде про формування нового сектору національної економіки. Варто нагадати, що протягом десятиліть адміністративної економіки такого сектору взагалі не існувала. У трансформаційний період відчувалася нестача кваліфікованих підприємців. В основної маси населення, що виживала в умовах гіперінфляції, не залишалося резервів та засобів, необхідних для започаткування власної справи.

До основних причин, які гальмують розвиток малого та середнього бізнесу в Україні, українські науковці-дослідники відносять такі:

- декларативний характер державної підтримки підприємства, що супроводжується неоднозначністю та суперечливістю чинної нормативно-правової бази; 
О. Пукало

Теоретичні проблеми та перспективи ...

- організаційно-правові труднощі започаткування бізнесу, особливо на етапі від реєстрації до початку його діяльності;

- обмеженість матеріальних фінансових ресурсів (наприклад, недоступність кредитних ресурсів як для започаткування, такі для ведення бізнесу чи його відновлення, недостатні зв'язки з міжнародними фрінансовими організаціями щодо залучення інвестицій і грантів);

- існуюча система обліку та статистичної звітності малого підприємництва, обмеженість інформаційного та консультативного забезпечення, система навчання та перепідготовки персоналу для підприємницької діяльності тощо $[6,17]$. Варто закцентувати увагу на тому, що малі підприємства зосереджені головним чином у сфері послуг: торгівля; ремонт автомобілів, побутових виробів та предметів особистого вжитку; операції з нерухомістю; оренда; інжиніринг та надання послуг підприємцям; промисловість та будівництво тощо $[7,63-75]$.

Проведений нами аналіз дав змогу виокремити ряд додаткових, негативних чинників, які гальмують розвиток малого бізнесу в Україні, зокрема:

- громіздка система бухгалтерського обліку, фінансової та податкової звітності, що спричиняють додаткові витрати для підприємств;

- економічно необґрунтована система оподаткування;

- недосконала чинна нормативно-правова база;

- недостатність цільових та регіональних програм розвитку та підтримки малого підприємництва;

- недосконала практика використання державних кредитних ліній для підтримки малого підприємництва;

- загроза виникнення кризи неплатежів та проблеми з формуванням нових взаємозв'язків, каналів збуту;

- складність пошуку фрінансових ресурсів для інвестиційного розвитку;

- трудомісткий і потребуючий значних фрінансових ресурсів процес реєстрації новостворених підприємств;

- неспроможність залучення кваліфрікованих фрахівців та забезпечення їм гідної оплати праці;

- обмеженість інформаційного та консультативного забезпечення;

- відсутність стимулів для інвестиційної діяльності.

Проте, узагальнюючи позитивні та негативні сторони розвитку малого бізнесу в Україні, можемо стверджувати, що сучасний розвиток цього сектору економіки практично не відповідає європейським показникам і відчутно відстає від європейських стандартів. Так, статистичні дані засвідчують, що частка малих та середніх підприємств у валовому внутрішньому продукті України становить лише 9\%, тоді як у країнах з ринковою економікою сягає 50-65\%. Дохід від реалізації продукції виконаних (робіт, послуг) виробничих малих підприємств сягає лише 2,3\% від загального обсягу продукції, яку випускає промисловість України [8].

Варто зазначити, що малі підприємства фрінансують свій подальший розвиток із отриманого доходу - на наше переконання, підприємствам необхідно залишати більшу частину доходу у себе. Це посилило б рівень інвестиційної привабливості малого бізнесу. Такий крок може сприяти готовності нових підприємців до ризику і вкладання своїх фінансових та інших ресурсів як у новостворювані фрірми, так і у вже існуючі компанії. Ми 
вважаємо, що зниження обсягу оподаткування допомогло б українським малим підприємствам стати менш залежним від іноземних капіталовкладень та урядових кредитних ліній.

Суттєві труднощі для підприємців та малого бізнесу створює існуюча нестабільна система оподаткування, необхідність удосконалення механізму оподаткування у бік його спрощення, оскільки безперечним фактом $€$ те, що порівняно з іншими країнами 3 перехідною економікою, підприємства та підприємці в Україні витрачають багато часу на вирішення питань регулятивного характеру. Сьогодні надмірні регулятивні вимоги, а також часті зміни в цих вимогах призводять до величезних фрінансових затрат з боку українського приватного підприємництва. Максимальне спрощення регулятивних актів також уможливило б зниження рівня існуючої корупції.

Українські та іноземні інвестори вважають, що чинні фінансові звіти об'єктивно не відображають реального стану підприємства. Така невизначеність стримує інвесторів від капіталовкладень, які за інших обставин були б доцільними і прибутковими. Тому, на наш погляд, в Україні доцільно запровадити загальновживані бухгалтерські засади, які уможливили б малим підприємствам доступ до вільного використовування амортизаційних засобів підприємництва.

Потенціал малих підприємств в Україні значний, тому у нас немає жодних сумнів щодо України у перспективах їх розвитку. Однак для реалізації цих перспектив дуже важливо, щоб ресурси, ризик та ініціатива були тісніше пов'язані між собою. Такого поєднання можна досягти, перш за все, надавши максимальні можливості підприємцям вільно розвивати малий бізнес та, відповідно, отримувати адекватну винагороду за свої зусилля.

Комплексні кроки щодо розв'язання цього завдання пропонує 3. Варналій [9, 58-64]. Згрупувавши їх, можемо виявити найголовніші:

1) впровадження спрощеної системи бухгалтерського обліку та звітності малих підприємств, а також розроблення єдиної системи реєстрації та легалізації суб'єктів підприємництва;

2) формування та розвиток системи фінансової підтримки малого підприємництва, для чого в першу чергу необхідно: внести зміни та доповнення до Закону України “Про систему оподаткування" та інші закони, в яких передбачити скорочення кількості зборів та відрахувань, перехід на єдиний сукупний податок, введення системи патентів для громадян-підприємців (фрізичних осіб), звільнення від оподаткування частини прибутку (доходу), що спрямовується на рефінансування суб'єктів малого підприємництва;

3) забезпечення надання малим підприємствам, що підпадають під державні цільові програми підтримки малого підприємництва, державних гарантій, у тому числі, у вигляді високоліквідних державних боргових зобов'язань;

4) впровадження віднесених на собівартість витрат, пов'язаних з формуванням страхового фонду (резерву на покриття можливих витрат) під час кредитування малих підприємств;

5) організація інформаційного, консультативного та кадрового забезпечення, насамперед відновлення щоквартальної статистичної звітності про діяльність суб'єктів малого підприємництва, а також організація підготовки та перепідготовки кадрів через систему бізнес-центрів, інкубаторів та технопарків. 
О. Пукало

Теоретичні проблеми та перспективи ...

На наш погляд, імплементація низки перелічених кроків потребує удосконалення структури освітніх програм з питань підприємницької діяльності. Це, без сумніву, допоможе залучити широкі верстви населення до отримання практичних знань щодо започаткування та успішного ведення власного бізнесу. Важливим освітнім моментом для ведення малого підприємництва єпоширення практики проведення конфреренцій, семінарів, круглих столів, форумів, міжнародних зустрічей тощо.

Засадничими, на нашу думку, є: нагальність створення та ефективний розвиток мережі регіональних і місцевих фондів з підтримки підприємництва, запровадження прогресивного механізму кредитно-гарантійної та фінансової допомоги; регулярне проведення виставок і ярмарок продукції, виробленої суб'єктами малого підприємництва з метою стимулювання випуску конкурентоспроможних товарів вітчизняних підприємств [10, 22].

Висновки та перспективи подальших досліджень. Таким чином, мале підприємництво - невід'ємна складова ринкової економіки, що надає їй гнучкості, мобілізує фінансові та виробничі ресурси, пришвидшує темпи науково-технічного прогресу, розв'язує нагальну проблему зайнятості населення, а також формує економічно самостійний і стабільний середній клас.

Тому усебічна підтримка малого підприємництва та побудова соціально орієнтованої економіки у перспективі має стати головним вектором динамічного розвитку і реформування економіки України, що сприятиме стабільному підвищенню рівня життя населення та зміцненню фрінансового становища країни загалом. Саме $з$ малим підприємництвом пов'язуємо надію на позитивні зміни в економіці країни і поглибленні ринкових реформ.

\section{Список використаних джерел}

1. Закон України “Про підприємство”, № 688-XII від 7.02.1991 року.

2. Про розвиток та державну підтримку малого і середнього підприємництва в Україні: Закон України [Електронний ресурс]. - Режим доступу : http://zakon 2.rada.gov.uallaws/show/4618-17.

3. Кампо Г. М. Управління розвитком малого бізнесу регіону: авторефр. дис. на здобуття наук. ступеня канд. екон. наук:спец. 08.00.05/Г. М. Кампо; Ужгородський національний університет. - Ужгород, 2009. -21 c.

4. Мале підприємництво в Україні: зб. нормативно-правових актів /за ред. О. В. Кужель, А. К. Кінаха, В. В. Костицького. - К. : Інститут законодавчих передбачень і правової експертизи, 1999. - 190 с.

5. Кузьмін О. Є. Форми та умови участі підприємств малого бізнесу у функціонуванні локальних ринків / О. Є. Кузьмін // Діловий вісник. - 2005. - № 2. - С. 22.

6. Іванілов О. С. Економіка підприємства / О. С. Іванілов. -К., 2009. - 728 с.

7. Плоткін Я. Д. Підприємцю про підприємництво: навч. посіб. / Я. Д. Плоткін. Львів, 2003. - С. 63-75.

8. Зосименко Т. І. Роль малого підприємництва у соціально-економічному розвитку краӥни [Електронний ресурс] / Т. І. Зосименко. -Дніпропетровськ : Електронне наукове фрахове видання “Ефективна економіка". -2013 р. - № 10.

9. Варналій 3. С. Тенденції становлення малого підприємництва в Україні / 3. С. Варналій // Ринкові перетворення . - К. : Т-во “Знання”КОО, 2003. -С. 58-64. 
10. Сідун О. Я. Регіональні механізми розвитку малого підприємництва (на матеріалах Закарпатської області): авторефр. дис. на здобуття наук. ступеня канд. екон. наук: спец. 08.06.01/ О. Я. Сідун. -Ужгород, 2004. - 22 c.

\section{References}

1. Zakon Ukrainy "Pro pidpryiemnytstvo", № 688-XII vid 7.02.1991 roku [The Law of Ukraine "On Entrepreneurship", No 688-XII, 07 February 1991] [in Ukrainian].

2. Pro rozvytok ta derzhavnu pidtrymku maloho i serednoho pidpryiemnytstva v Ukraini: Zakon Ukrainy [The Law of Ukraine "On Development and State Support of Small and Medium-sized Enterprises in Ukraine"], from http://zakon 2.rada.gov.ua/laws/show/461817 [in Ukrainian].

3. Kampo H. M. Upravlinnia rozvytkom maloho biznesu rehionu: avtoref. dys. na zdobuttia nauk. stupenia kand. ekon. nauk: spets. 08.00 .05 [Management of small businesses development on the regional level: extended abstract of dissertation for the academic degree of Candidate of Economics in specialty 08.00.05]. Uzhhorod, 2009, 21 p. [in Ukrainian].

4. Male pidpryiemnytstvo v Ukraini: zb. normatyvno-pravovykh aktiv. Za red. O. V. Kuzhel, A. K. Kinakha, V. V. Kostytskoho [Small entrepreneurship in Ukraine: a collection of legal and regulatory acts].Kyiv, 1999, 190 p. [in Ukrainian].

5. Kuzmin O. Ye. Formy ta umovy uchasti pidpryiemstv maloho biznesu u funktsionuvanni lokalnykh rynkiv [Forms and conditions for the participation of small businesses in the functioning of local markets]. Dilovyi visnyk - The BusinessHerald, 2005, No. 2, p. 22 [in Ukrainian].

6. Ivanilov O. S. Ekonomika pidpryiemstva [Economics of enterprises]. Kyiv, 2009, 728 p. [in Ukrainian].

7. Plotkin Ya. D. Pidpryiemtsiu pro pidpryiemnytstvo: navch. posib. [For entrepreneur about entrepreneurship]. Lviv, 2003, pp. 63-75 [in Ukrainian].

8. Zosymenko T. I. Rol maloho pidpryiemnytstva u sotsialno-ekonomichnomu rozvytku krainy [The role of smal entrepreneurship in social and economic growth of the country]. Elektronne naukove fakhove vydannia Efektyvna ekonomika-E-journal Efficient Economy, 2013, No. 10 [in Ukrainian].

9. Varnalii Z. S. Tendentsii stanovlennia maloho pidpryiemnytstva $v$ Ukraini [Trends small businesses growth in Ukraine]. Rynkovi peretvorennia - Market transformation, Kyiv, 2003, pp. 58-64 [in Ukrainian].

10. Sidun O. Ya. Rehionalni mekhanizmy rozvytku maloho pidpryiemnytstva (na materialakh Zakarpatskoi oblasti): avtoref. dys. na zdobuttia nauk. stupenia kand. ekon. nauk: spets. 08.06.01 [Regional mechanisms of small businesses growth: extended abstract of dissertation for the academic degree of Candidate of Economics in specialty 08.06.01]. Uzhhorod, 2004, 22 p. [in Ukrainian].

Редакція отримала матеріал 25 вересня 2017 р. 